\title{
Demand Allocation and Profit Sharing to Improve Salt Farmer's Revenue: A Cooperative Game Approach
}

\section{Iffan Maflahah}

University of Trunojoyo Madura https://orcid.org/0000-0002-4940-6445

Budi Santoso Wirjodirdjo ( $\nabla$ budisantoso.wirjodirdjo@gmail.com )

Sepuluh Nopember Institute of Technology https://orcid.org/0000-0002-9463-1393

\section{Putu Dana Karningsih}

Sepuluh Nopember Institute of Technology https://orcid.org/0000-0002-2367-3449

\section{Research Article}

Keywords: Cooperative game, horizontal collaboration, revenue, Shapley value, vertical collaboration

Posted Date: December 21st, 2021

DOl: https://doi.org/10.21203/rs.3.rs-1188072/v1

License: (1) (i) This work is licensed under a Creative Commons Attribution 4.0 International License.

Read Full License 


\title{
Demand Allocation and Profit Sharing to Improve Salt Farmer's Revenue: A Cooperative Game Approach
}

\author{
Iffan Maflahah"12, Budisantoso Wirjodirdjo ², Putu Dana Karningsih²
}

\begin{abstract}
The main problem of the salt supply chain system is the oligopoly market structure dominated by middlemen which reduces the bargaining power of farmers. It has, however, been discovered that vertical collaboration (farmers to cooperatives) and horizontal collaboration (farmers to farmers) models have the ability to increase farmers' revenue. Therefore, this research was conducted to determine the effect of both horizontal and vertical collaboration models on the salt supply chain system with the expectation to increase farmers' revenue. This involved the application of the cooperative game theory with Shapley's value used as the basis for decision making. The result showed that the collaboration of stakeholders in the salt supply chain system has the ability to increase farmers' revenue, especially when they sell a maximum of $20 \%$ of their products through cooperatives and the rest through middlemen. This means the existence of farmers as cooperative members has a positive impact as observed in the revenue increment. Therefore, it is recommended that cooperatives improve their functions and roles as providers of savings and loans and market seekers, determine the appropriate prices for salt, and improve the quality of the products produced by their members. Moreover, a collaboration between farmers is mutually beneficial and this means efforts should be made to ensure cooperation, especially for small farmers.
\end{abstract}

Keywords: Cooperative game, horizontal collaboration, revenue, Shapley value, vertical collaboration

\section{Introduction}

Salt is an essential commodity included in the nine basic ingredients usually requested by communities in Indonesia (Anonymous 1994). This means it is necessary to maintain the stability of its supplies and prices in the domestic market. It was discovered that the country imports salt from other countries due to the inability of domestic production to meet national demand despite its potential self-sufficiency. This is observed from the ratio of production capability to salt demand recorded not to be more than 0.5 from 2014 - 2019 (BPS 2019). Some of the problems associated with the imbalance between the availability and demand for salt include the lack of supply due to the distortion of the supply chain system and an average increase in salt consumption per year to 5.5\% (KKP 2019; BPS 2019). Moreover, the increase in national salt demand is not accompanied by more domestic production due to the lack of motivation for farmers not obtaining corresponding revenue for their production efforts. It is important to note that the salt supply chain system in Indonesia is very long and complex due to the involvement of several stakeholders working independently within the system (Baekhaki, Kinseng, and Soetarto 2018; Holis, Sayyidi, and Musoffan 2019). This has been discovered to cause impartiality in farmer's revenue.

The supply chain system has also been reported to be inefficient (Holis, Sayyidi, and Musoffan

\footnotetext{
Iffan Maflahah

iffanmaflahah@gmail.com

$\triangle$ Budi Santoso Wirjodirdjo

budisantoso.wirjodirdjo@gmail.com

Putu Dana Karningsih

putu.karningsih@gmail.com

${ }^{1}$ Department of Agro-industrial Technology, Faculty of Agriculture, University of Trunojoyo Madura, Bangkalan 69162, Indonesia

2 Department of Industrial Engineering, Faculty of Industrial Technology, Sepuluh Nopember Institute of

Technology, Surabaya 60111, Indonesia
} 
2019; Widiyastutik, Hapsari, and Kuntadi 2016; Jamil and Netti 2015) and tends to take the form of an imperfectly competitive market known as oligopoly (SAVE 2005). This type of market structure allows the domination of one member of the supply chain system which is the middlemen acting as the collectors, buyers, and liaison officers for the markets and marketers (Biglaiser and $\mathrm{Li}$ 2018; Watanabe 2018). The role of the middlemen is very dominant to the extent that they determine the price for both the farmers and buyers (Minoo 2017; Biglaiser and Li 2018). This means the oligopolistic tendencies limit the powers of the farmers in determining salt prices and allow them to only act as recipients of prices determined by the middlemen (Wulandari et al. 2021; Sasongko and Satrianto 2021; Chandra and Sao 2020). It is also important to note that the farmers have limited information on prices in the market and this makes it difficult for them to bargain with the middlemen (Mustofa et al. 2021).

The salt price at the farmer's level in Indonesia between 2016 - 2019 was reported to have ranged from IDR 200 to IDR 600 per kilogram (Sudaryana and Pramesti 2018; Suhendi, Abdullah, and Shalihati 2020) while the minimum required to be accepted by the farmers is IDR 900 per kilogram. The government also tried to regulate the price but it was not effective (Effendy, Zainuri, and Hafiluddin 2014) due to the activities of the middlemen. Moreover, salt was imported to meet domestic demand (Maflahah and Asfan 2020; Suhendi, Abdullah, and Shalihati 2020) and the government also made efforts towards improving the supply chain system by enhancing productivity and regulating price to the farmer's level. This was considered necessary to increase revenue for the farmers by improving their ability to bargain.

Studies have been conducted to improve the salt supply chain system by determining the active role of cooperatives in increasing the revenue of salt farmers (Holis, Sayyidi, and Musoffan 2019; Mustofa et al. 2021). It was discovered that the collaboration between farmers and cooperatives is vertical (Zhong et al. 2018) with the cooperatives expected to reduce the role of the middlemen in the system to ensure the process becomes more advantageous. Other studies also showed the possibility of increasing farmers' revenue through horizontal collaboration among the farmers (Joffre, Poortvliet, and Klerkx 2019; Martins, Trienekens, and Omta 2019).

Most of the previous studies on salt supply chain system has been conducted using the qualitative descriptive approach, descriptive statistics, margin share calculation approach (Widiyastutik, Hapsari, and Kuntadi 2016; Pusat Kebijakan Perdagangan Dalam Negeri (Puska DN) 2012; Jamil and Netti 2015; Mannar and Yusufali 2013; Rinardi and Rochwulaningsih 2017), SWOT (Holis, Sayyidi, and Musoffan 2019; Y. Liu, Han, and Wei 2016; Muensriphum et al. 2010), system dynamics (Muhandhis et al. 2021), and supply - chain operations reference method (Ming, Junwen, and Xiaoyan 2008; Purnanto, Suadi, and Ustadi 2020). This present study, however, provides an overview of the alternative salt supply chain system including the activities conducted, production costs, marketing costs, salt handling costs, and profit from each element of the system. This is necessary considering the fact that the previous research did not describe the collaborative model of the system.

A game theory approach was adopted to provide an overview of the collaboration expected to increase farmers' revenue. This is a mathematical approach usually used in formulating and analyzing competitive situations and conflicts between players and the results were used for the interactive decision-making process involving more than one decision-maker with different goals (Maschler, Solan, and Zamir 2013; Brown and Shoham 2008). The approach has been widely used to determine alternative options of supply chain channels for agricultural products towards providing adequate revenue for the stakeholders (Courtois and Subervie 2014; Prasad, Shankar, and Roy 2019; Chen et al. 2018; Z. Liu et al. 2018; Song and Zhuang 2017; Behzadi et al. 2018; Tabrizi, Ghodsypour, and Ahmadi 2018). Its development includes the description of the behavior of stakeholders such as the farmers and buyers. It is, however, important to note that middlemen and cooperatives are the buyers in this case.

This study applied coalition game theory to develop the collaboration model of the salt supply chain while the concept of transferable utility was used in the cooperative game. Moreover, each member in the coalition is assumed to have agreed with the price determined by the buyer and the agreement includes a permit on the payoff to be distributed among the members (Maschler, Solan, and Zamir 2013; Brown and Shoham 2008). The number of players is more than two, they all support the common interest, and are involved in the coalition. It is important to note that the coalition game theory is widely used to allocate product supply (M. Deng, Xiang, and Yao 2018; Bonamini et al. 2019) and determine alternative channels of the supply chain (Gao, Yang, and Liu 2017). Furthermore, the salt supply chain-system model shows that the members including the farmers, middlemen, and cooperatives have different interests. Therefore, a hybrid collaboration including farmers to cooperatives (vertical collaboration) and farmers to farmers (horizontal 
collaboration) is proposed to be more suitable in this study to improve the system. This model is expected to increase farmers' revenue through the flexibility in selecting the alternative supply chain systems developed. This research aims to determine the effect of the horizontal and vertical collaboration models in the salt supply chain system on farmers' revenue based on the Shapley value obtained from the coalition.

\section{Methodology}

\subsection{Cooperative Game Theory}

The cooperative game theory was used in this system and it consists of two elements which include (1) a set of players and (2) a characteristic function which determines the value generated by different subsets of players in a game. The cooperative games do not focus on how individual players make their personal choices in a coalition but on the payoff received by the coalition. This payoff determines the benefits obtained by a player at the end of the game. It is important to note that an agreement or partnership is the basis of the mathematical model of a cooperative game called the coalition (Aoki 1984; Brown and Shoham 2008).

Mathematically, a coalition is a subset of the set of $\mathrm{N}$ players and represented by symbol $\mathrm{S}$ and requires an agreement involving all players for its formation. This agreement binds the agents in the coalition as a new, coordinated entity with a particular arrangement designed for its members symbolizing its denotation. Moreover, the Grand Coalition consists of all players without any empty coalition and a game consisting of $\mathrm{n}$ players has the ability to form $2 \mathrm{n}$ possible coalitions. It is also important to note that the coalition structure is a way to describe how players divide themselves into independent coalitions with each division explained by a set $\mathrm{S}=(\mathrm{S} 1, \mathrm{~S} 2, \ldots, \mathrm{Sm})$ of $\mathrm{m}$ coalitions formed.

The problem-solving element widely used in cooperative game theory is the Shapley value (Shapley 1953) which is based on the concept of characteristic function and Shapley's axiom. This value is usually used as an index to measure the strength of players in a game. Some of the definitions used are as follows:

Definition 1 (Ferguson 2014; Shapley 1953; Thomas 1986): Coalition games (N, v) with transferable payoffs consist of:

- A limited set of $\mathrm{N}$ (number of players)

- The function $\mathrm{v}$ is called the characteristic function of a game in a real number $\mathrm{v}(\mathrm{S})$.

- The function $\mathrm{v}(\mathrm{S})$ is the payoff of $\mathrm{S}$ for any set $\mathrm{S}$ that is non-empty $\varnothing$ of $\mathrm{N}$.

- The characteristic function $\mathrm{v}(\mathrm{S})$ defined for all coalitions $\mathrm{S}$ is a vector:

$$
x=\left(x_{1}, x_{2}, \ldots, x_{n}\right)
$$

satisfying:

$$
x_{1}+x_{2}+x_{3}+x_{4}+x_{5}=v(N) \text {, }
$$

where $\mathrm{N}$ is the set for each player

$$
x_{1} \geq v(i), \text { for } \mathrm{i}=1,2, \ldots, \mathrm{n}
$$

The empty set $\varnothing$ is known as the empty coalition while the set of $\mathrm{N}$ is called the grand coalition. Moreover, the function v(S) is the total available coalitions for all members of $\mathrm{S}$ with a transferable payoff. The model assumptions used are as follows:

$$
v(S)+v(T) \leq v(S \cup T)
$$

For all S and T where $S \cap T=\emptyset$. This formula indicates the revenue earned from a coalition is required to be more than the amount received when a member does not join the coalition. This condition is called the superadditive.

Definition 2 (Shapley 1953; Thomas 1986): The values obtained by Shapley through axiomatic methods including the value of a game $\mathrm{v}$ with $\mathrm{n}$-vectors, $\varphi_{i}(v)$, which meets the following axioms: 
If $\mathrm{xx}$ is the carrier of $\mathrm{xx}$, then

$$
\sum_{S} \varphi(v)=v(S)
$$

For every permutation $\pi^{* *}$, e $i \in N$.

$$
\varphi_{\pi(i)} \pi v=\varphi_{i} v
$$

If $u$ and $v$ are two games,

$$
\varphi_{i} u\left|+v=\varphi_{i} u\right|+\varphi_{i} v \mid
$$

Therefore, the Shapley value was obtained from:

$$
\varphi_{i}(N, v)=\frac{1}{|N| !} \sum_{S \subseteq N}(s-1) !([N\rceil-s) !(v(S)-v(S \backslash\{[i\rceil\}))
$$

where the number of players in the coalition $\mathrm{S}, \forall \mathrm{i} \in N$.

Equation 7 was used to calculate the Shapley value after all the possible coalitions have been determined where each player has a number of $2^{n}-1$. It is also possible to use the Shapley value to calculate the exact contribution of each player in each possible coalition.

The payoff value is the revenue of player $i$ in the coalition game $(N, v)$. Therefore, the payoff value in the game was denoted by the vector $\varphi(N, v)=\left(\varphi_{i}(N, v)\right)_{i \in N}$ and this means

$$
\sum_{i \in N} \varphi_{i}(N, v)=v(N)
$$

while $\Delta_{i}(S)=v(S)-v(S(j))$ is the marginal contribution of player $i$ to the coalition $\mathrm{S}$.

Definition 3 (Shapley 1953): Player $i$ is a dummy player in (N, v) if $v(S)-v(s\{i\})=v(\{i\})$ for any coalition $\mathrm{S}$ with $i$.

Definition 4 (Shapley 1953): The concept of Shapley's value is based on characteristic function and Shapley's axiom. When players $i$ and $j$ are interchangeable on $(\mathrm{N}, \mathrm{v})$, if $v(S\{i\})=v(S\{j\}), \forall S \subseteq N$, then, there are three axioms of justice placed on a function $\varphi$ which are:

1. Symmetry: If $i$ and $j$ are interchangeable in $(\mathrm{N}, \mathrm{v})$, then, $\varphi_{\mathrm{i}}(\mathrm{N}, \mathrm{v})=\varphi_{\mathrm{j}}(\mathrm{N}, \mathrm{v})$

2. Dummy: If $i$ is a dummy player in $(\mathrm{N}, \mathrm{v})$, then, $\varphi_{\mathrm{i}}(\mathrm{N}, \mathrm{v})=\mathrm{v}(\{\mathrm{i}\})$

3. Additivity: If there are two games $v$ and $w$, then, $\varphi_{\mathrm{i}}(\mathrm{v}+\mathrm{w})=\varphi_{\mathrm{i}}(\mathrm{v})+\varphi_{\mathrm{i}}(\mathrm{w})$ for every $i \in \mathrm{N}$, where $(v+w)(S)=v(S)+w(S), \forall S \subset \subseteq N$

\subsection{Model Formulation}

The solution to the problem observed in the salt supply chain system is the development of a model using the coalition principle. Meanwhile, the members of this system involved in the coalition are defined as follows:

1. Farmers: salt producers with different amounts of supply

2. The middlemen: intermediary traders that buy salt from farmers, usually determine prices, and purchase products on site.

3. Cooperative: a business entity consisting of salt farmers formulated through people's economic movement and kinship.

The salt supply chain coalition consists of vertical and horizontal models as indicated in Figure 1. The horizontal coalition is between the farmers and usually involves a transaction between those with shortage and those with excess salt at a lower price than middlemen. The provisions also allow a deferred payment system for the farmers selling the products. Meanwhile, the vertical coalition is between the farmers and cooperatives with the farmers required to be members of a cooperative and, at the same time, mandated to sell their products at a certain amount through the cooperative which acts as the wholesaler and plays an active role in the market. 


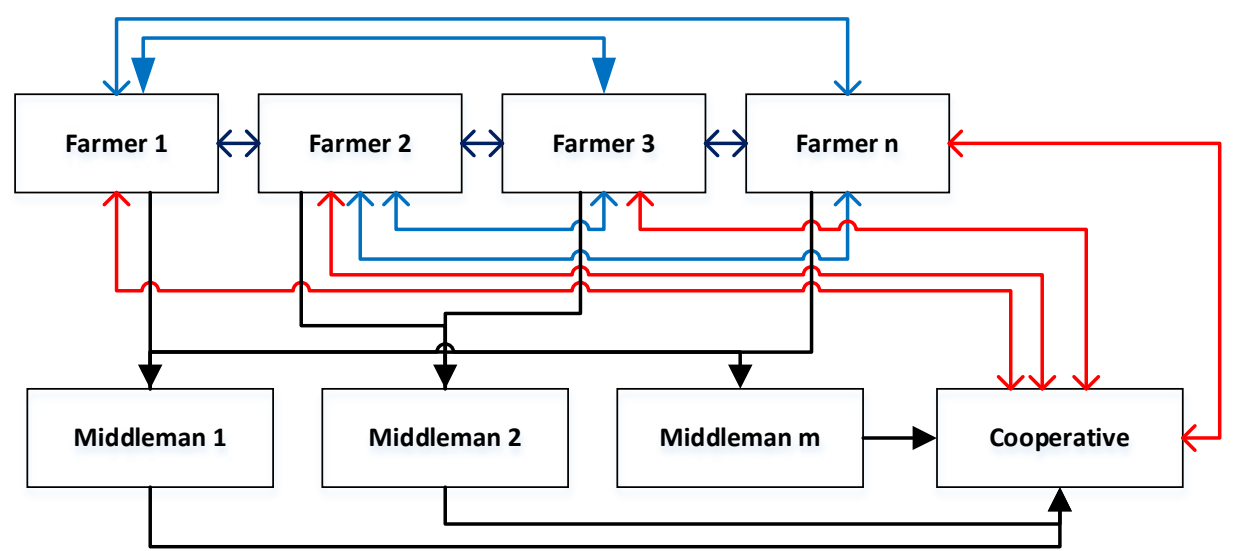

\section{$\leftrightarrow \quad$ : Vertical Collaboration \\ $\leftrightarrow \quad$ : Horizontal Collaboration \\ $\rightarrow$ : Non Collaboration}

Fig. 1. The Salt Supply Chain Coalition Model

This study made use of six players in the coalition which include farmer 1 , farmer 2, farmer 3 , farmer 4 , farmer 5 , and farmer 6 . Therefore, the characteristic function was formulated as follows in line with Definition 1:

$x_{1}+x_{2}+x_{3}+x_{4}+x_{5}+x_{6}=v\{1,2,3,4,5,6\}$

$x_{1} \geq v(1) ; x_{2} \geq v(2) ; x_{3} \geq v(3) ; x_{4} \geq v(4) ; x_{5} \geq v(5) ; x_{6} \geq v(6)$.

The Shapley values are also as follows:

$$
x^{*}=x=\left(x_{1}^{*}, x_{2}^{*}, x_{3}^{*}, x_{4}^{*}, x_{5}^{*}, x_{6}^{*}\right)
$$

The model describes the average contribution of each of these six stakeholders or farmers when joining the coalition $\{1,2,3,4,5,6\}$ in all possible stages. Moreover, the payoff used in calculating Shapley's value was the amount of income each player earns which was based on the total income of the members in the supply chain system. The amount of income of the trading system members also depends on the choice of the supply chain channel (Naseer et al. 2019; Arinloye et al. 2014; Guarín 2013; Muthini 2016). Furthermore, the acceptance of each element in the system was based on the quantity of salt sold and the price agreed by the middlemen or cooperatives and the farmers.

The development of the salt supply chain system includes $i^{\text {th }}$ farmer $(i=1,2, \ldots, n), j^{\text {th }}$ middleman $(\mathrm{j}=1,2, \ldots, \mathrm{m})$, and $\mathrm{k}^{\text {th }}$ cooperatives $(\mathrm{k}=1,2, \ldots, \mathrm{h})$ while the quantity supplied by farmers and the price offered by middlemen depend on the $t^{\text {th }}$ time $(t=1,2, \ldots, l)$. Moreover, the quantity of salt demanded from the middleman $j$ at time $t$ is $D a_{j t}$ and those from cooperatives $k$ at time $t$ is $D b_{k t}$ while the farmers' supply Sit is sold to middlemen at $q a_{j i t}$ and cooperatives at $q b_{k i t}$. It is, however, important to note that the price and quantity of products sold by producers in the supply chain channel determine the revenue (Muthini 2016). The middleman and farmers usually agree on the selling price but the price is generally determined by the trader. In this study, each middleman $j$ has a different purchase price for farmer $i$ at time $t$ which is $p a_{j i t}$ while the price offered by the cooperative $k$ to all i farmers at time $t$ is $p b_{k i t}$. Meanwhile, the middlemen and cooperatives sell the salt in retail to the market at a price $p m_{t}$.

The middleman's revenue was earned from selling the products purchased from the farmer in the market by considering the transaction fee $\mathrm{Ca}$ for each salt transport capacity $\mathrm{G}$. The transaction fees charged reduces the prices given by the middlemen (Ndoro, Mudhara, and Chimonyo 2014). Therefore, the middleman's revenue $j\left(\pi a_{j t}\right)$ at time $t$ is generally defined as follows:

$$
\pi a_{j t}=\sum_{t=1}^{l} \sum_{i=1}^{n} \sum_{j=1}^{m}\left(p m_{t}-p a_{j i t}\right) \min \left(q a_{i j t}, D a_{j t}\right)-C a \sum_{t=1}^{l} \sum_{i=1}^{n} \sum_{j=1}^{m} \frac{\min \left(q a_{i j t}, D a_{j t}\right)}{G}
$$


The cooperative's revenue was obtained from purchasing salt from farmer $i$ and profit-sharing. It is important to note that the farmer is $(1-\beta)$ while the membership fee is $C m_{i}$. Moreover, the supply chain system through the use of cooperatives bears the risk of market uncertainty (Hao et al. 2018; Kontogeorgos et al. 2018; Abebaw and Haile 2013), and this as well as as the transaction costs $(\mathrm{Cb})$ for each salt transport capacity $\mathrm{G}$ is shared with the farmers at $\left(\frac{(1-\vartheta)}{2}\right)$ when the salt is sold in the market. The total revenue for the cooperative $k$ at time $t\left(\pi b_{k t}\right)$ is, therefore, generally defined as follows:

$$
\begin{aligned}
& \pi b_{k t}=\left(\sum_{t=1}^{l} \sum_{i=1}^{n} \sum_{k=1}^{h}\left(p m_{t}-p b_{k t}\right) * \min \left(q b_{k i t}, D b_{k t}\right)\right)+(1-\beta) \sum_{t=1}^{l} \sum_{i=1}^{n} q b_{k i t} * \\
& \left.\left(p m_{t}-p b_{k t}\right)\right)+\sum_{i=1}^{n} \sum_{t=1}^{l} C m_{i t}-\left(\left(\frac{(1-\vartheta)}{2}\right) \sum_{t=1}^{l} \sum_{i=1}^{n} \sum_{k=1}^{h}\left(\left(p m_{t}-p b_{k t}\right)\right) *\right. \\
& \left.\min \left(q b_{k i t}, D b_{k t}\right)\right)-C b \sum_{t=1}^{l} \sum_{i=1}^{n} \sum_{k=1}^{h}\left(\frac{\min \left(q b_{k i t}, D b_{k t}\right)}{G}\right)
\end{aligned}
$$

The revenue of farmer $i$ at time $t\left(\pi_{f i t}\right)$ is the total revenue from middlemen $j$ and cooperatives $k$. Farmer $i$ does not have to conduct business with cooperatives and the cooperatives can also receive salt from farmers without membership. Moreover, the percentage of salt sold by farmer $i$ through middlemen $j$ at time $t$ is $q a_{j i t}$ and through cooperatives $k$ at time $t$ is $q b_{k i t}$. A farmer i that collaborates with cooperatives has to bear half of the total risks which is $\vartheta$ percent and receive a profit-sharing $\beta$. The farmer also needs to abide by the transaction fee $\mathrm{C}$ and pay the membership fee $C m_{i t}$.

Several conditions regarding the revenue of farmers obtained through horizontal coalition which involves one or more farmers with products higher than demand from middlemen and cooperatives selling to those with lesser quantity. There are three types of models related to such revenue and these include:

(i) The revenue of farmers that only sell based on the amount of supply they have ( $\boldsymbol{S}_{i t} \leq \boldsymbol{D a} \boldsymbol{a}_{j t}+$ $D b_{k t}$ )

In this case, farmer $i$ only sells salt based on the amount of supply owned. The revenue is, therefore, obtained from the quantity sold through middlemen $j$ and cooperative $k$. Moreover, the farmer also receives a share of profits from sales through cooperatives but bears the risk of market uncertainty, pays a cooperative membership fee every time of $\mathrm{Cm}_{i t}$, and a transaction fee $\mathrm{C}$ when collaborating with the cooperative according to the transport capacity $(\mathrm{G})$ of the transportation mode used. Therefore, the revenue of farmer $i$ at time $t\left(\pi_{f i t}\right)$ is, generally, as follows:

$$
\begin{aligned}
& \pi_{f i t}=\left(\sum_{t=1}^{l} \sum_{i=1}^{n} \sum_{j=1}^{m} p a_{j i t} * \min \left(q a_{j i t}, D a_{j t}\right)\right)+\left(\sum_{t=1}^{l} \sum_{i=1}^{n} \sum_{k=1}^{h} p b_{k t} *\right. \\
& \left.\min \left(q b_{k i t}, D b_{k t}\right)\right)+\beta \sum_{t=1}^{l} \sum_{i=1}^{n} \sum_{k=1}^{h}\left(q b_{k i t} *\left(p m_{t}-p b_{k t}\right)\right)-(C b * \\
& \left.\left(\frac{m i n\left(q b_{k i t}, D b_{k t}\right)}{G}\right)\right)-\left(C \sum_{t=1}^{l} \sum_{i=1}^{n} \sum_{k=1}^{h}\left(\frac{q b_{k i t}}{G}\right)\right)-\left(\sum _ { t = 1 } ^ { l } \sum _ { i = 1 } ^ { n } \sum _ { k = 1 } ^ { h } \left(\frac { ( 1 - \vartheta ) } { 2 } \left(p m_{t}-\right.\right.\right. \\
& \left.\left.\left.p_{b k t}\right)\right) \min \left(q b_{k i t}, D b_{k t}\right)\right)-\sum_{i=1}^{n} \sum_{t=1}^{l} C m_{i t}
\end{aligned}
$$

(ii) The revenue of farmers that buy salt from other farmers

In this case, farmer $i$ sells the quantity of salt owned and some quantity purchased from other farmers. This means farmer $i$ needs to pay other farmers with excess supply at a lower price which is $r$ percent of the middlemen price. The revenue obtained by the farmer is, therefore, from the quantity sold through middlemen $j$ and cooperative $k$ as well as the share of profits from sales through the cooperatives. However, farmer $i$ needs to bear the risk of market uncertainty with the cooperatives as members, pay a membership fee of $\mathrm{Cm}_{i t}$ every time, and a transaction fee of when collaborating with the cooperative according to the transport capacity (G) of the transportation mode used. Therefore, the revenue of farmer $i$ at time $t\left(\pi_{f i t}\right)$ is, generally, as follows:

$$
\begin{aligned}
& \pi_{f i t}=\left(\sum_{t=1}^{l} \sum_{i=1}^{n} \sum_{j=1}^{m} p a_{j i t} * \min \left(q a_{j i t}, D a_{j t}\right)\right)+\left(\sum_{t=1}^{l} \sum_{i=1}^{n} \sum_{k=1}^{h} p b_{k t} *\right. \\
& \left.\min \left(q b_{k i t}, D b_{k t}\right)\right)-\left(\sum_{t=1}^{l} \sum_{i=1}^{n} \sum_{k=1}^{h}\left(\frac{(1-\vartheta)}{2} \min \left(p m_{t}-p_{b t}\right)\right) * \min \left(q b_{i t}, D b_{k t}\right)\right)+ \\
& \left(\beta \sum_{t=1}^{l} \sum_{i=1}^{n} \sum_{k=1}^{h}\left(q b_{k i t} *\left(p m_{t}-p b_{k t}\right)\right)-\left(C b *\left(\frac{\min \left(q b_{k i t}, D b_{k t}\right)}{G}\right)\right)\right)-
\end{aligned}
$$




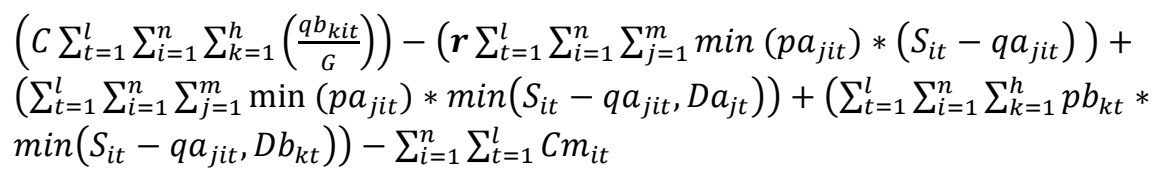

(iii) The revenue of farmers with supply of salt which exceeds the demand consists of revenue from middlemen, cooperatives, and coalitions with other farmers ( $\left.\boldsymbol{S}_{\boldsymbol{i t}} \geq \boldsymbol{D a _ { j t }}+\boldsymbol{D} \boldsymbol{b}_{\boldsymbol{k} t}\right)$

This involves a coalition among farmers based on the assumption that a farmer has supplies more than the quantity demanded. The revenue of such farmer is usually from the middlemen, cooperatives, and coalitions made with other farmers and this is generally represented in the following model:

$$
\begin{aligned}
& \pi_{f i t}=\left(\sum_{t=1}^{l} \sum_{i=1}^{n} \sum_{j=1}^{m} p a_{j i t} * \min \left(q a_{j i t}, D a_{j t}\right)\right)+\left(\sum_{t=1}^{l} \sum_{i=1}^{n} \sum_{k=1}^{h} p b_{k t} *\right. \\
& \left.\min \left(q b_{k i t}, D b_{k t}\right)\right)-\left(\sum_{t=1}^{l} \sum_{i=1}^{n} \sum_{k=1}^{h}\left(\frac{(1-\vartheta)}{2}\left(p m_{t}-p_{b t}\right)\right) * \min \left(q b_{i t}, D b_{k t}\right)\right)+ \\
& \beta \sum_{t=1}^{l} \sum_{i=1}^{n} \sum_{k=1}^{h}\left(q b_{k i t} *\left(p m_{t}-p b_{k t}\right)\right)-\left(C b *\left(\frac{\min \left(q b_{k i t}, D b_{k t}\right)}{G}\right)\right)- \\
& \left(C \sum_{t=1}^{l} \sum_{i=1}^{n} \sum_{k=1}^{h}\left(\frac{q b_{k i t}}{G}\right)\right)+\boldsymbol{r} \sum_{t=1}^{l} \sum_{i=1}^{n} \sum_{j=1}^{m} \min \left(p a_{j i t}\right) *\left(S_{i t}-q a_{j i t}\right)- \\
& \sum_{i=1}^{n} \sum_{t=1}^{l} C m_{i t}
\end{aligned}
$$

\section{Results and Discussion}

Some supporting data are required to ensure the coalition among farmers, middlemen, and cooperatives in the salt supply chain have the ability to increase the farmer revenue. It is important to reiterate that this research used six farmers $1,2,3,4,5$, and 6 each with a different quantity of salt to be supplied depending on the area of land and season as indicated in Table 1. The fulfillment of demand was determined by the quantity supplied by each farmer with the total demand discovered to consist of those made by the middlemen in Table 2 and cooperatives in Table 3. Moreover, the farmers selected their preferred channel for the supply chain system based on the price of each middleman as observed in Table 4. Meanwhile, other data such as the price of salt in the cooperative, transaction costs, and other variables were also needed to determine the total revenue of each member in the supply chain system as shown in Table 5.

Table 1. Supply salt (tons) $\left(\boldsymbol{S}_{i t}\right)$

\begin{tabular}{cccccccccc}
\hline $\begin{array}{c}\text { Farmer } \\
\text { (i) }\end{array}$ & $\mathbf{1}$ & $\mathbf{2}$ & $\mathbf{3}$ & $\mathbf{4}$ & $\mathbf{5}$ & $\mathbf{6}$ & $\mathbf{7}$ & $\mathbf{8}$ & $\mathbf{9}$ \\
\hline $\mathbf{1}$ & 10 & 28 & 43 & 52 & 58 & 59 & 56 & 48 & 37 \\
\hline $\mathbf{2}$ & 16 & 45 & 68 & 83 & 92 & 94 & 89 & 77 & 58 \\
\hline $\mathbf{3}$ & 6 & 16 & 24 & 30 & 33 & 34 & 32 & 28 & 21 \\
\hline $\mathbf{4}$ & 3 & 9 & 14 & 17 & 19 & 20 & 19 & 16 & 12 \\
\hline $\mathbf{5}$ & 28 & 81 & 122 & 150 & 166 & 169 & 160 & 138 & 105 \\
\hline $\mathbf{6}$ & 3 & 5 & 6 & 7 & 8 & 8 & 7 & 7 & 6 \\
\hline
\end{tabular}

Table 2. Salt demands in each middlemen for each period (tons) $\left(\boldsymbol{D} \boldsymbol{a}_{\boldsymbol{j} t}\right)$

\begin{tabular}{cccccccccc}
\hline $\begin{array}{c}\text { Middlemen } \\
\text { (j) }\end{array}$ & $\mathbf{1}$ & $\mathbf{2}$ & $\mathbf{3}$ & $\mathbf{4}$ & $\mathbf{5}$ & $\mathbf{6}$ & $\mathbf{7}$ & $\mathbf{8}$ & $\mathbf{9}$ \\
\hline $\mathbf{1}$ & 54 & 153 & 230 & 283 & 313 & 319 & 302 & 261 & 198 \\
\hline $\mathbf{2}$ & 32 & 92 & 138 & 170 & 188 & 191 & 181 & 157 & 119 \\
\hline $\mathbf{3}$ & 23 & 61 & 92 & 113 & 125 & 128 & 121 & 105 & 79 \\
\hline
\end{tabular}

Table 3. Salt demands in each cooperative to a farmer for each period (tons) ( $\left.\boldsymbol{D} \boldsymbol{b}_{i t}\right)$

\begin{tabular}{cccccccccc}
\hline $\begin{array}{c}\text { Farmer } \\
\text { (i) }\end{array}$ & $\mathbf{1}$ & $\mathbf{2}$ & $\mathbf{3}$ & $\mathbf{4}$ & $\mathbf{5}$ & $\mathbf{6}$ & $\mathbf{7}$ & $\mathbf{8}$ & $\mathbf{9}$ \\
\hline $\mathbf{1}$ & $\mathbf{1 2}$ & 36 & 53 & 66 & 73 & 74 & 70 & 61 & 46 \\
\hline $\mathbf{2}$ & 20 & 57 & 85 & 104 & 115 & 118 & 112 & 97 & 73 \\
\hline $\mathbf{3}$ & 7 & 20 & 31 & 38 & 42 & 42 & 40 & 35 & 26 \\
\hline $\mathbf{4}$ & 4 & 12 & 18 & 22 & 24 & 25 & 23 & 20 & 15 \\
\hline $\mathbf{5}$ & 35 & 102 & 153 & 188 & 208 & 212 & 201 & 174 & 131 \\
\hline
\end{tabular}




\begin{tabular}{llllllllll}
\hline 6 & 1 & 3 & 5 & 6 & 7 & 7 & 7 & 6 & 4 \\
\hline
\end{tabular}

Table 4. Middlemen price for each period (IDR ooo /tons) $\left(\boldsymbol{p} \boldsymbol{a}_{\boldsymbol{j i t}}\right)$

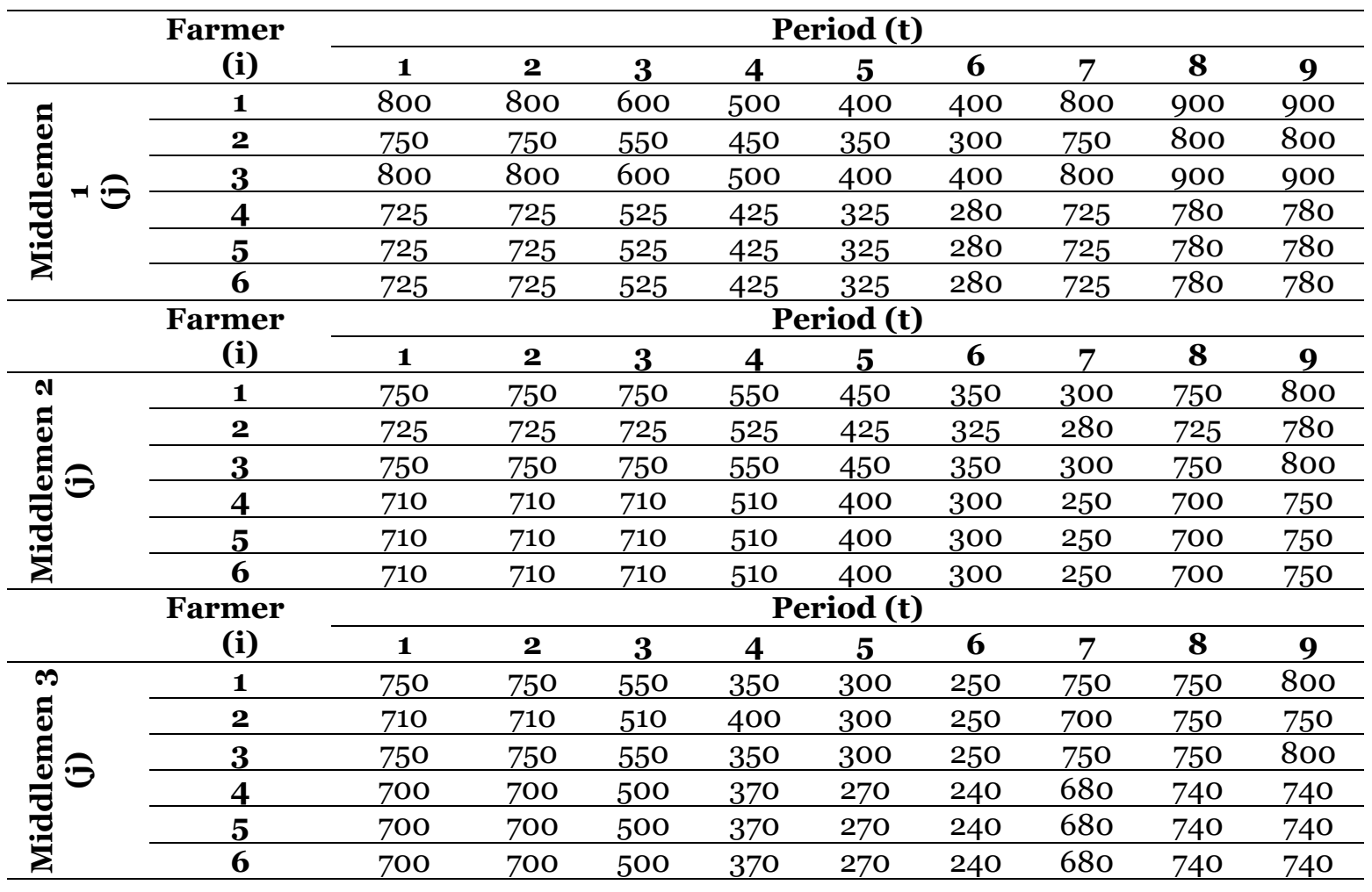

Table 5. Other Variables Used

\begin{tabular}{cll}
\hline Variable & \multicolumn{2}{c}{ Variable Description } \\
\hline$P m_{t}$ & The price of salt in the market in period t (IDR/tons) & $\mathbf{1 , 2 0 0 , 0 0 0}$ \\
\hline $\mathrm{Pb}_{\mathrm{kt}}$ & Cooperative salt price k in period t (IDR/tons) & $\mathbf{1 , 1 0 0 , 0 0 0}$ \\
\hline $\mathrm{G}$ & Salt Carrying capacity (tons) & 9 \\
\hline$\vartheta$ & Risk of selling through cooperatives (\%) & 8 \\
\hline$\beta$ & Percentage of profit-sharing between cooperatives and farmers & 15 \\
\hline $\mathrm{C}$ & Transaction costs from land to cooperatives (IDR/tons) & 45,000 \\
\hline $\mathrm{Ca}$ & Salt transaction costs by middlemen to the market (IDR/tons) & 97,000 \\
\hline $\mathrm{Cb}$ & Transaction fee from cooperative to market (IDR/tons) & 45,000 \\
\hline$r$ & Percentage drop in salt price & 40 \\
\hline$C m_{i t}$ & Cooperative membership fee (IDR/period) & 30,000 \\
\hline
\end{tabular}

Tables 1-5 show a scenario where the farmers sell to middlemen 1, middlemen 2, middlemen 3 , and cooperatives. The initial scenario involves the farmers conducting transactions through all the salt supply-chain system channels without a coalition. This involves selling $30 \%$ of the total production through middlemen 1, 20\% through middlemen 2, 20\% through middlemen 3 , and another $20 \%$ through cooperatives. The revenue of these farmers was determined by the quantity sold to each member in the system as indicated in Table 6.

Table 6. Total revenue of non-coalition Farmers

\begin{tabular}{ccccccc}
\hline & Farmer 1 & Farmer 2 & Farmer 3 & Farmer 4 & Farmer 5 & Farmer 6 \\
\hline $\begin{array}{c}\text { Total } \\
\text { Revenue } \\
\text { (IDR) }\end{array}$ & $260,704,056$ & $395,828,278$ & $149,190,000$ & $82,233,278$ & $690,057,278$ & $36,516,444$ \\
\hline
\end{tabular}

The coalition game scenario is based on the horizontal coalition which involved simulating six farmers considered to be willing to cooperate. The coalition conducted by the farmers was expected to produce a minimum amount of revenue which is equal to or greater than those obtained before forming the coalition. For example, farmer 1 forms a coalition with farmer 2 and this provides game 
value which is the total revenue of each farmer. It is important to note that the revenue is expected to be higher than the revenue obtained from selling without a coalition. There are, however, possibilities associated with the coalition game consisting of six players which are described as follows:

- $\quad$ Coalition with one player (6 possibilities)

- $\quad$ Coalition with two players (15 possibilities)

- Coalition with three players (20 possibilities)

- $\quad$ Coalition with four players (14 possibilities)

- $\quad$ Coalition with five players (6 possibilities)

- Coalition with six players (1 possibility) which is known as the grand coalition

The characteristic functions formed in the coalition of six farmers for each coalition according to Definition 1 are presented in Table 7. The solution proposed for the problem based on the Shapley value (Shapley 1953; Thomas 1986) showed that the concept rationally considered the contribution or role of each player in the largest coalition. Therefore, the Shapley values of the six players used in this case are as follows:

$$
x^{*}=x=\left(x_{1}^{*}, x_{2}^{*}, x_{3}^{*}, x_{4}^{*}, x_{5}^{*}, x_{6}^{*}\right)
$$

Table 7. Characteristics of the v(S) function based on the farmers' supply

\begin{tabular}{|c|c|c|c|c|c|}
\hline Coalition & $\begin{array}{c}\text { Total Revenue } \\
v(S)\end{array}$ & Coalition & $\begin{array}{c}\text { Total Revenue } \\
v(\mathbf{S})\end{array}$ & Coalition & $\begin{array}{c}\text { Total Revenue } \\
v(\mathbf{S})\end{array}$ \\
\hline 1 & $260,704,056$ & $3-2-1$ & $805,328,450$ & $5-3-2-1$ & $1,496,212,817$ \\
\hline 2 & $395,828,278$ & $4-2-1$ & $738,197,667$ & $5-4-2-1$ & $1,429,082,033$ \\
\hline 3 & $149,190,000$ & $4-3-1$ & $490,826,500$ & $5-4-3-1$ & $1,181,710,867$ \\
\hline 4 & $82,233,278$ & $4-3-2$ & $626,372,133$ & $5-4-3-2$ & $1,317,256,500$ \\
\hline 5 & $690,057,278$ & $5-2-1$ & $1,347,835,567$ & $6-3-2-1$ & $840,720,667$ \\
\hline 6 & $36,516,444$ & $5-3-1$ & $1,100,464,400$ & $6-4-2-1$ & $773,589,883$ \\
\hline $2-1$ & $656,951,200$ & $5-3-2$ & $1,236,010,033$ & $6-4-3-1$ & $526,218,717$ \\
\hline $3^{-1}$ & $409,580,033$ & $5-4-1$ & $1,033,333,617$ & $6-4-3-2$ & $661,764,350$ \\
\hline $3-2$ & $545,125,667$ & $5-4-2$ & $1,168,879,250$ & $6-5-2-1$ & $1,383,227,783$ \\
\hline 4-1 & $342,449,250$ & $5-4-3$ & $921,508,083$ & $6-5-3-1$ & $1,135,856,617$ \\
\hline $4-2$ & $477,994,883$ & $6-2-1$ & $692,343,417$ & $6-5-3-2$ & $1,271,402,250$ \\
\hline $4-3$ & $230,623,717$ & $6-3-1$ & $444,972,250$ & $6-5-4-1$ & $1,068,725,833$ \\
\hline $5-1$ & $952,087,150$ & $6-3-2$ & $580,517,883$ & $6-5-4-2$ & $1,204,271,467$ \\
\hline $5-2$ & $1,087,632,783$ & $6-4-1$ & $377,841,467$ & $6-5-4-3$ & $956,900,300$ \\
\hline $5-3$ & $840,261,617$ & $6-4-2$ & $513,387,100$ & $5-4-3-2-1$ & $1,569,740,283$ \\
\hline $5-4$ & $773,130,833$ & $6-4-3$ & $266,015,933$ & $6-4-3-2-1$ & $921,967,133$ \\
\hline $6-1$ & $296,595,000$ & $6-5-1$ & $987,479,367$ & $6-5-3-2-1$ & $1,530,643,033$ \\
\hline $6-2$ & $432,140,633$ & $6-5-2$ & $1,123,025,000$ & $6-5-4-2-1$ & $1,463,512,250$ \\
\hline $6-3$ & $184,769,467$ & $6-5-3$ & $875,653,833$ & $6-5-4-3-1$ & $1,217,103,083$ \\
\hline $6-4$ & $117,638,683$ & $6-5-4$ & $808,523,050$ & $6-5-4-3-2$ & $1,352,648,717$ \\
\hline $6-5$ & $727,276,583$ & $4-3-2-1$ & $886,574,917$ & $6-5-4-3-2-1$ & $1,612,851,500$ \\
\hline
\end{tabular}

Shapley value $(260,892,343 ; 396,353,694 ; 149,321,506 ; 82,225,534 ; 691,308,254 ;$ 37,750,168)

The formula is the imputation which represents the average contribution of each of the six players when joining the $\{1,2,3,4,5,6\}$ coalition in all possible stages. This means the farmers joined the game randomly and when a player, for example, farmer 1 arrives at some of the existing $\mathrm{S}$ coalitions, the contribution made to improve the game is defined as:

$$
v(S \cup 1)-v(S)
$$

Suppose a large coalition of six farmers was formed in such a way that player 5 was initially in a coalition with player 6 , then player 4 joins the coalition $\{6,5\}$, player 3 joins the coalition $\{6,5,4\}$, player 2 joins the coalition $\{6,5,4,3\}$, and finally player 1 joins the coalition $\{6,5,4,3,2\}$. Therefore, when farmer 6 joins the coalition $\{6,5,4,3,2,1\}$, the contribution to this grand coalition is only $v(\{6\})$ $=\mathrm{v}(6)=36.516 .444$ based on Table 7 .

This study was required to note that the $\{6,5,4,3,2,1\}$ coalition is the same as the $\{1,2,3,4,5,6\}$ coalition. Therefore, when player 5 joined player 6 , player 5 added a value of $v\{6,5\}-v(\{5\})=$ 
$727,276,583-36,516,444=690,760,139$. Similarly, when player 4 joined the coalition of players $\{6,5\}$, a value of $v\{6,5,4\}-v(\{6,5\})=808,523,050-727,276,583=81,246,467$ was added and when player 3 joined $\{6,5,4\}$, a value of $\mathrm{v}\{6,5,4,3\}-\mathrm{v}(\{6,5,4\})=956,900,300-808,523,050=$ $148,377,250$ was also added. Moreover, the additional value when player 2 joined the coalition $\{6,5,4,3\}$ was $\mathrm{v}\{6,5,4,3,2\}-\mathrm{v}(\{6,5,4,3\})=1,352,648,717-956,900,300=395,748,417$ while the contribution of player 1 after joining $\{6,5,4,3,2\}$ was $v\{6,5,4,3,2,1\}-v(\{6,5,4,3,2\})=1,612,851,500$ $-1,352,648,717=260,202,783$.

The grand coalition combinations were formulated up to $6 !-1=719$ different ways of combining $\{6,5,4,3,2,1\}$. It is important to note that there are other sets of players apart from the order presented as indicated by the sequence of a group of other players from the same large coalition such as $\{2,5,4,6,1\}$. Meanwhile, the calculation from the coalition $\{6,5,4,3,2,1\}$ and other sequences was based on permutations as indicated in Table 8.

Table 8. Contribution of each player (farmers) (IDR)

\begin{tabular}{|c|c|c|c|c|}
\hline \multirow[t]{2}{*}{ Contribution } & \multicolumn{4}{|c|}{ Order of creation of a grand coalition } \\
\hline & $\{6-4-1-2-5-3\}$ & $\{5-2-6-1-3-4\}$ & $\{4-2-6-1-3-5\}$ & $\{1-2-3-4-5-6\}$ \\
\hline Farmer 1 & $260,202,783$ & $260,202,783$ & $260,202,783$ & $260,704,056$ \\
\hline Farmer 2 & $395,748,417$ & $397,575,505$ & $395,761,605$ & $396,247,144$ \\
\hline Farmer 3 & $148,377,250$ & $147,415,250$ & $148,377,250$ & $148,377,250$ \\
\hline Farmer 4 & $81,246,467$ & $82,208,467$ & $82,233,278$ & $81,246,467$ \\
\hline Farmer 5 & $690,760,139$ & $690,057,278$ & $690,884,367$ & $683,165,366$ \\
\hline Farmer 6 & $36,516,444$ & $35,392,217$ & $36,392,217$ & $43,111,217$ \\
\hline Total & $1,612,851,500$ & $1,612,851,500$ & $1,612,851,500$ & $\mathbf{1 , 6 1 2 , 8 5 1 , 5 0 0}$ \\
\hline
\end{tabular}

The procedure of the Shapley value showed there are still $5 !-2=118$ remaining permutations and the results were averaged for each farmer. Therefore, the imputation is as follows:

$$
x=\left(x_{1}^{*}, x_{2}^{*}, x_{3}^{*}, x_{4}^{*}, x_{5}^{*}, x_{6}^{*}\right)
$$

Theorem 1: The Shapley values for cooperative games with characteristic functions presented in Table 7 was imputation 260,892,343, 396,353,694, 149,321,506, 82,225,534, 691,308,254, and $37,750,168$. The coordinate value of this vector was divided by the total revenue of each farmer $1,2,3$, 4,5 , and 6 with the Shapley value found to be $100,45 \%, 100,386 \%, 100,76 \%, 101,22 \%, 100,33 \%$, and $106,29 \%$ respectively. This shows the revenue earned was increasing. Moreover, this was followed by the Shapley value theorem in Definition 1 (super additive) which requires the revenue value of each player at the time of the coalition to be greater than or equal to the situation without coalition (Ferguson 2014; Thomas 1986).

Theorem 2: The Shapley values for cooperative games with characteristic functions presented in Table 4 were the essence of this game.

Evidence: Table 9 verifies the revenue of 260,892,343, 396,353,694, 149,321,506, 82,225,534, $691,308,254$, and 37,750,168 offered in the Shapley solution:

$$
x=\left(x_{1}^{*}, x_{2}^{*}, x_{3}^{*}, x_{4}^{*}, x_{5}^{*}, x_{6}^{*}\right)
$$

Each number of farmers for all $63=25-1$ coalition with a number greater than the value determined by the characteristic function is presented in Table 7 and an example of the coalition verified was $\{1,3,6\}$. The total revenue obtained for this particular coalition using the Shapley's solution is as follows:

$$
447,964,017=260,892,343+149,321,506+37,750,168
$$

The value of the characteristic function was found to be smaller than the Shapley value in line with the assumptions of $v\{1,3,6\}=444,972,250$ in Table 7 . This is in accordance with the Shapley value concept in Definition 1 which showed that v(S) is the maximum value guaranteed with the $S$ coalition by coordinating the strategies of its members regardless of the activities of other players (Shapley 1953; Thomas 1986). 
Table 9 Total revenue in each coalition based on the Shapley value

\begin{tabular}{rrrrrr}
\hline Coalition & \multicolumn{1}{c}{$\begin{array}{c}\text { Total } \\
\text { Revenue } \boldsymbol{v}(\mathbf{S})\end{array}$} & Coalition & $\begin{array}{c}\text { Total } \\
\text { Revenue } \boldsymbol{v}(\mathbf{S})\end{array}$ & Coalition & \multicolumn{1}{c}{$\begin{array}{c}\text { Total } \\
\text { Revenue } \boldsymbol{v}(\mathbf{S})\end{array}$} \\
\hline $260,892,343$ & $3^{-2-1}$ & $806,567,543$ & $5-3-2-1$ & $1,497,875,797$ & $260,892,343$ \\
\hline
\end{tabular}

The same steps in calculating the Shapley value were applied for Scenario 1 where the sales through middlemen 1 were $30 \%$, middlemen 2 were $40 \%$, middlemen 3 were $20 \%$, and cooperatives were $10 \%$. It was also observed in Scenario 2 with $30 \%, 30 \%, 20 \%$, and 20\%, Scenario 3 with $25 \%$, $25 \%, 25 \%$, and $25 \%$, Scenario 4 with $40 \%, 20 \%, 10 \%$, and $30 \%$, Scenario 5 with $10 \%, 30 \%, 20 \%$, and 40\%, and Scenario 6 with 20\%, 10\%, 10\%, and 60\% respectively as indicated in Table 10.

Table 10. Recapitulation of total farmers coalition revenue based on sales scenario

\begin{tabular}{|c|c|c|c|c|}
\hline Scenario & Farmer & $\begin{array}{c}\text { Non- } \\
\text { Coalition } \\
\text { Revenue }\end{array}$ & $\begin{array}{l}\text { Coalition } \\
\text { Revenue }\end{array}$ & Difference \\
\hline \multirow{6}{*}{$\begin{array}{l}\text { Middlemen } 1(30 \%) \\
\text { Middlemen } 2(40 \%) \\
\text { Middlemen } 3(20 \%) \\
\text { Cooperative (10\%) }\end{array}$} & Farmer 1 & $243,387,389$ & $244,534,635$ & $1,147,246$ \\
\hline & Farmer 2 & $366,952,000$ & $368,267,811$ & $1,315,811$ \\
\hline & Farmer 3 & $137,712,389$ & $138,727,715$ & $1,015,326$ \\
\hline & Farmer 4 & $74,940,389$ & $75,889,755$ & 949,366 \\
\hline & Farmer 5 & $637,051,611$ & $638,733,866$ & $1,682,255$ \\
\hline & Farmer 6 & $34,640,778$ & $35,553,500$ & 912,722 \\
\hline \multirow{6}{*}{$\begin{array}{l}\text { Middlemen } 1(30 \%) \\
\text { Middlemen } 2(30 \%) \\
\text { Middlemen } 3(20 \%) \\
\text { Cooperative (20\%) }\end{array}$} & Farmer 1 & $259,704,056$ & $260,892,343$ & $1,188,288$ \\
\hline & Farmer 2 & $394,828,278$ & $396,353,694$ & $1,525,417$ \\
\hline & Farmer 3 & $148,190,000$ & $149,321,506$ & $1,131,506$ \\
\hline & Farmer 4 & $81,233,278$ & $82,225,534$ & 992,257 \\
\hline & Farmer 5 & $689,057,278$ & $691,308,254$ & $2,250,977$ \\
\hline & Farmer 6 & $35,516,444$ & $37,750,168$ & $2,233,723$ \\
\hline \multirow{7}{*}{$\begin{array}{l}\text { Middlemen } 1(25 \%) \\
\text { Middlemen } 2(25 \%) \\
\text { Middlemen } 3(25 \%) \\
\text { Cooperative }(25 \%)\end{array}$} & Farmer 1 & $268,642,500$ & $253,232,224$ & $-1,4410,276$ \\
\hline & Farmer 2 & & & - \\
\hline & & $406,880,667$ & $379,846,621$ & $27,034,045$ \\
\hline & Farmer 3 & $154,610,667$ & $152,501,711$ & $-2,108,955$ \\
\hline & Farmer 4 & $83,958,833$ & $91,782,501$ & $7,823,668$ \\
\hline & Farmer 5 & $715,618,944$ & $688,818,410$ & $-26,800,534$ \\
\hline & Farmer 6 & $41,912,556$ & $57,685,132$ & $15,772,576$ \\
\hline \multirow{6}{*}{$\begin{array}{l}\text { Middlemen } 1(30 \%) \\
\text { Middlemen } 2(20 \%) \\
\text { Middlemen } 3(20 \%) \\
\text { Cooperative (30\%) }\end{array}$} & Farmer 1 & $280,367,500$ & $229,070,616$ & $-51,296,884$ \\
\hline & Farmer 2 & $425,896,556$ & $344,557,344$ & $-81,339,211$ \\
\hline & Farmer 3 & $159,667,889$ & $148,357,211$ & $-11,310,678$ \\
\hline & Farmer 4 & $87,837,389$ & $93,356,064$ & $5,518,675$ \\
\hline & Farmer 5 & $746,306,167$ & $642,410,310$ & $-103,895,857$ \\
\hline & Farmer 6 & $38,972,778$ & $58,212,822$ & $19,240,044$ \\
\hline \multirow{6}{*}{$\begin{array}{l}\text { Middlemen } 1(10 \%) \\
\text { Middlemen } 2(30 \%) \\
\text { Middlemen } 3(20 \%) \\
\text { Cooperative (40\%) }\end{array}$} & Farmer 1 & $286,275,667$ & $139,751,363$ & $-146,524,304$ \\
\hline & Farmer 2 & $445,879,333$ & $256,108,616$ & $-189,770,717$ \\
\hline & Farmer 3 & $162,823,278$ & $97,865,772$ & $-64,957,506$ \\
\hline & Farmer 4 & $92,661,278$ & $68,514,982$ & $-24,146,296$ \\
\hline & Farmer 5 & $785,696,833$ & $455,197,936$ & $-330,498,897$ \\
\hline & Farmer 6 & $40,897,389$ & $51,719,798$ & $10,822,409$ \\
\hline \multirow{6}{*}{$\begin{array}{l}\text { Middlemen } 1(20 \%) \\
\text { Middlemen } 2(10 \%) \\
\text { Middlemen } 3(10 \%) \\
\text { Cooperative (60\%) }\end{array}$} & Farmer 1 & $345,486,722$ & $-4,185,144$ & $-349,671,866$ \\
\hline & Farmer 2 & $536,597,389$ & $102,267,560$ & $-434,329,829$ \\
\hline & Farmer 3 & $197,284,000$ & $-7,735,555$ & $-205,019,555$ \\
\hline & Farmer 4 & $108,354,389$ & $-18,080,154$ & $-126,434,542$ \\
\hline & Farmer 5 & $781,929,333$ & $76,210,175$ & $-705,719,158$ \\
\hline & Farmer 6 & $49,964,778$ & $77,691,584$ & $27,726,806$ \\
\hline
\end{tabular}

Another important function of the coalition game theory model apart from the determination of the farmers' revenue is the ability to describe the amount of cooperative revenue which was divided into coalition and non-coalition as indicated in Figure 2. The coalition aspect involves the revenue obtained with the cooperation of the farmers as members which are required to pay membership fees and sell a certain quantity of salt to the cooperative. Meanwhile, the non-coalition aspect involves farmers that sell their salt to the cooperative without being members. 


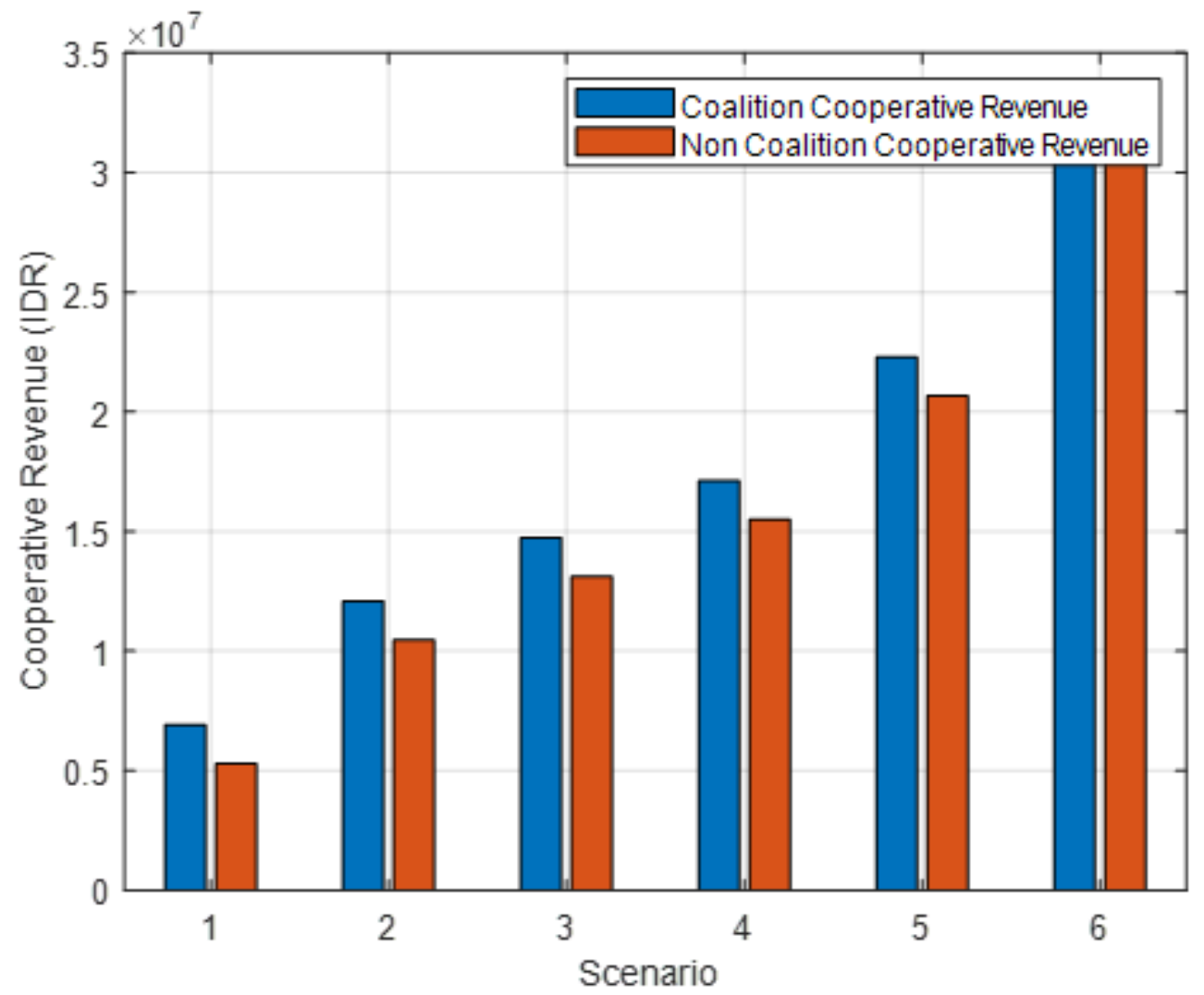

Fig. 2. Total Cooperative Revenue

Description: Scenario 1 (Cooperative 10\%); Scenario 2 (20\%); Scenario 3 (25\%);

Scenario 4 (30\%), Scenario 5 (Cooperative 40\%); Scenario 6 (Cooperative 60\%).

Figure 2 shows the cooperative's revenue increased as the farmers sold extra salt. It was discovered that the cooperative had a revenue of IDR 6,920,000 when $10 \%$ was purchased from the farmers and recorded IDR $17,122,500$ when $30 \%$ was purchased. The same trend was also observed with the non-coalition revenue. Meanwhile, the total revenue from the coalition cooperatives when $10 \%$ was purchased was found to be IDR 6,920,000 while the non-coalition revenue was IDR $5,300,000$ and this indicates a difference of IDR 1,620,000 which is the value of membership fee of IDR 30,000 paid by many cooperative members for nine periods.

The amount of revenue obtained by the Middlemen was determined by the quantity of salt bought by each of them from the farmers as indicated in Figure 3. It was also discovered that a higher percentage of salt sales by farmers produced a greater income for the middlemen. For example, when all of the farmers sold $30 \%$ of total production through middleman 1 a total income of IDR 441,870,000 was generated by the middleman which was reduced to IDR 371,705,000 when it was $25 \%$ and IDR $148,745,000$ when it was $10 \%$. 


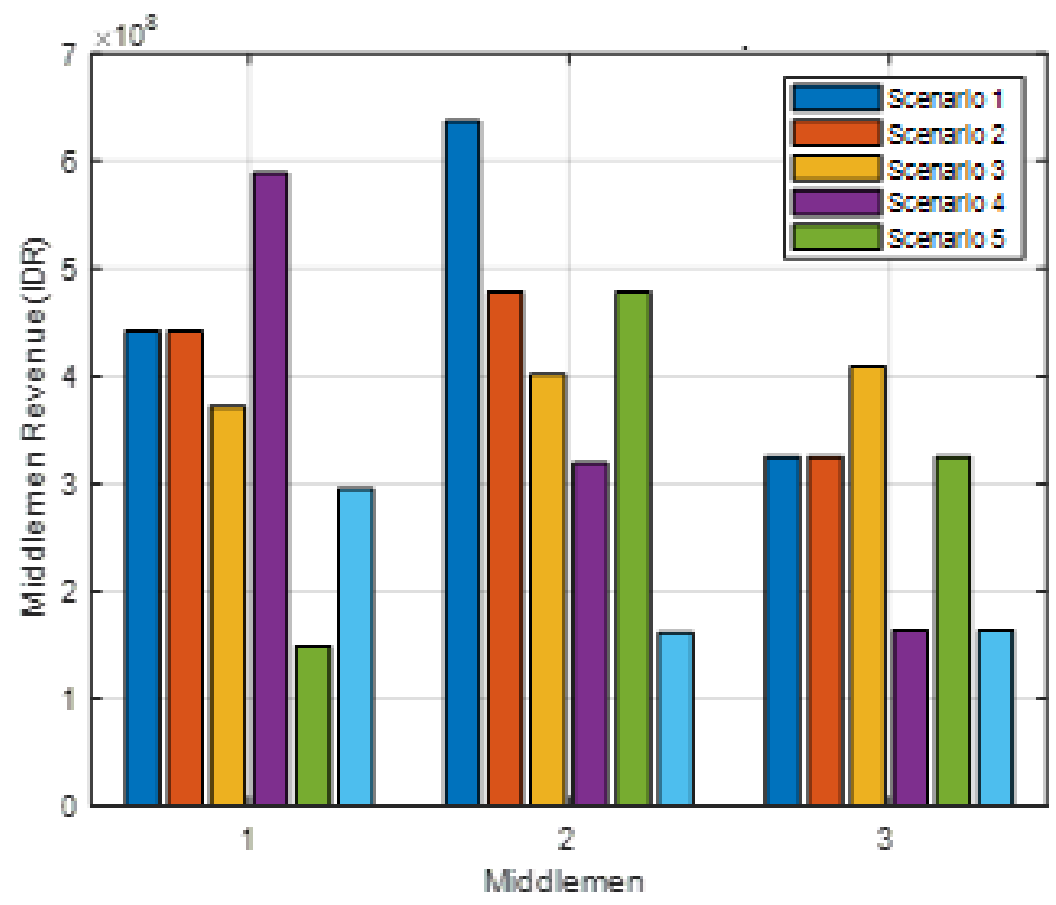

Fig. 3. The Revenue of Middlemen Based on Total Sales of Farmers

The farmer revenue presented in Table 10, cooperative revenue in Figure 2, and the concept of Shapley value in Definitions 1, 2, and 3 showed that Scenarios 1 and 2 provides higher income value for farmers when compared to selling without a coalition with other farmers. It was discovered from Scenario 1 that the revenue obtained by Farmer 1 was IDR 1,147,246, Farmer 2 IDR 1,315,811, Farmer 3 IDR 1,015,326, Farmer 4 IDR 949,366, Farmer 5 IDR 1,682,255, and Farmer 6 IDR 912,722. Moreover, the revenue generated in Scenario 2 for Farmer 1 was IDR 1,188,288, Farmer 2 IDR 1,525,417, Farmer 3 IDR 1,131,506, Farmer 4 IDR 992,257, Farmer 5 IDR 2,250,977, and Farmer 6 IDR 2,233,723. This means Scenarios 2 has highest increase in income. Moreover, the coalition revenue between farmers in Scenario 2 for Farmer 1 was IDR 260,892,343, Farmer 2 IDR 396,353,694, Farmer 3 IDR 149,321,506, Farmer 4 IDR 82,225,534, Farmer 5 IDR 691,308,254, and Farmer 6 was IDR 37,750,168.

There is a difference in the revenue to be received by the farmers through horizontal and vertical coalitions due to the number of sales in each different supply chain system channel, the quantity of salt owned by the farmers, and price information which has the ability to influence farmers' decisions. This is in line with the definition of (Hansen 2015; Hennessy and Heanue 2012) that horizontal coalition involves the interaction of several farmers participating in the supply chain system to share information and resources. This means vertical and horizontal coalitions are essential keys for farmers' performance (Martins, Trienekens, and Omta 2019). It is also important to note that the horizontal relationship among farmers regarding price information has the ability to influence their decisions on the alternative supply chain channels to be selected.

The scenarios designed based on the percentage of sales made by farmers to middlemen 1 , middlemen 2, middlemen 3 , and cooperatives with a coalition system showed the highest quantity sold through the cooperatives was $20 \%$. This is due to the fact that sales exceeding $20 \%$ usually lead to losses for the farmers. Meanwhile, the high revenue recorded was due to a large number of transaction costs the farmers are required to bear such as the membership fees paid at every period, handling of salt after harvest, transportation fees from the site to the cooperative, and other costs associated to risks.

The middlemen revenue decreased with the existence of cooperatives in the supply chain system. The role of the middlemen is, however, significant for the farmers due to their functions in the production process such as the provision of finances with a payment mechanism after harvest as reported by Chandra and Sao (Chandra and Sao 2020). The farmers prefer the supply chain system through intermediaries due to the fact that they do not want to incur any costs for the products to reach the market. The wholesalers bear all the costs for packaging, transportation, and market research. It is also important to note that all the transactions between farmers and middlemen are usually conducted in the salt ponds (Sasongko et al. 2019). Moreover, the farmers sell through the 
wholesalers without adding any value to the salt and this limits their ability to bargain for price (Mustofa et al. 2021). This means the revenue obtained by farmers through the middlemen in the supply chain system is their net revenue.

The existence of cooperatives is very beneficial to both parties as indicated by an increment in their respective revenues which led to an increase in the cooperative membership fees paid in each period for Scenario 1, Scenario 2, Scenario 3, Scenario 4, Scenario 5, and Scenario 6 as observed in Table 10. This is parallel to the findings of Ma et al. and Altman (Ma and Abdulai 2016; Altman 2015) that cooperatives have the ability to provide relatively higher revenues for their members, thereby, making it possible for agricultural products to compete in the market. It is important to note that the farmers do not need to research market price when form collaborating with cooperatives which are required to accept the quality and quantity of salt produced by the farmers. However, this system requires the farmers to bear the costs of handling, packaging, and transportation to the warehouses owned by the cooperatives. The farmers obtain more profits when they become members due to the fact that the cooperative buys salt at a different price from its members compared to non-members. This is in line with the findings of Deng et al. (H. Deng et al. 2010) that producers are willing to become cooperatives due to the service benefits enjoyed by the members such as the need not to commercialize their products, easy access to market, transaction costs reduction, and exemption from market uncertainty (Alho 2015). Moreover, the existence of cooperatives has the ability to improve product quality through the use of appropriate technology to increase the selling price of the products (Abebaw and Haile 2013). This was also observed from the (Heriansah and Fathuddin 2014; Widiyastutik, Hapsari, and Kuntadi 2016; Jamil and Netti 2015; Mannar and Yusufali 2013) which showed that the role of salt cooperatives is to organize training needed to increase salt production. However, the problem associated with these cooperatives is the considerable pressure to seek the market for sale when there are abundant products in an area (Grashuis 2018; Kontogeorgos et al. 2018; Milovanovic and Smutka 2018).

\section{Conclusions}

The Shapley value showed that the coalitions among farmers as well as between farmers and cooperatives provide a higher amount of revenue than the condition without a coalition. Moreover, a maximum sale of $20 \%$ of the total salt produced is recommended to be conducted through cooperatives due to the fact that the sales above this figure have the ability to cause losses for the farmers.

The coalition was observed to have increased the income of the farmers when they supply less than 10 tons of salt per period while those with a more significant offer than the coalition concept gains profit by selling $20 \%$ through cooperatives. This means the existence of cooperatives has the ability to assist farmers in increasing their income and improving their bargaining position by providing market certainty for their products. Cooperatives are, however, required to offer more services than middlemen to increase the membership of the farmers. They also need to reduce transaction costs to increase their revenue.

It is recommended that subsequent research involve other forms of collaboration with cooperatives to prove that the coalition between farmer and cooperative are more profitable when all parties contribute maximally. Moreover, the cooperation can be structured to provide different commissions according to the quantity of salt sold as well as different prices according to the quality of the salt produced. This is expected to spur the farmers to increase their productivity, quality, and quantity. Furthermore, cooperatives need to provide intensive assistance regarding the application of the appropriate technology.

\section{Conflicts of Interest: The authors declare no conflict of interest.}

\section{References}

Abebaw, Degnet, and Mekbib G. Haile. 2013. "The Impact of Cooperatives on Agricultural Technology Adoption: Empirical Evidence from Ethiopia." Food Policy 38 (1): 82-91. https://doi.org/10.1016/j.foodpol.2012.10.003.

Alho, Eeva. 2015. "Farmers' Self-Reported Value of Cooperative Membership: Evidence from Heterogeneous Business and Organization Structures." Agricultural and Food Economics 3 (1). https://doi.org/10.1186/s40100-015-0041-6.

Altman, Morris. 2015. "Cooperative Organizations as an Engine of Equitable Rural Economic Development." Journal of Co-Operative Organization and Management 3 (1): 14-23. 
https://doi.org/10.1016/j.jcom.2015.02.001.

Anonymous. 1994. "Keputusan Presiden Republik Indonesia Nomor 69 Tahun 1994 Tentang Pengadaan Garam Beriodium (Decree of the President of the Republic of Indonesia Number 69 of 1994 Concerning the Procurement of Iodized Salt).” Keputusan Presiden Republik Indonesia\%oANomor 69 tahun 1994 tentang pengadaan garam\%oAberiodium.

Aoki, Masahiko. 1984. The Co-Operative Game Theory of The Firm. New York: Oxford University Press.

Arinloye, Djalalou-dine A A, Stefano Pascucci, Anita R Linnemann, Ousmane N Coulibaly, Geoffrey Hagelaar, and Onno S.W.F Omta. 2014. "Marketing Channel Selection by Smallholder Farmers." Journal of Food Products Marketing, 1-21. https://doi.org/10.1080/10454446.2013.856052.

Baekhaki, Khamid, Rilus A. Kinseng, and Endriatmo Soetarto. 2018. "Korporatisasi Garam Rakyat : Dinamika Transisi Sosial, Ekonomi Dan Ekologi Petambak Garam (Corporatization of Salt Farmer: The Dynamic of Social Economic and Ecological Transitions)." Sodality 6 (1): 61-70. https://doi.org/10.22500/sodality.v6i1.21209.

Behzadi, Golnar, Michael Justin O'Sullivan, Tava Lennon Olsen, and Abraham Zhang. 2018. "Agribusiness Supply Chain Risk Management: A Review of Quantitative Decision Models." Omega (United Kingdom) 79: 21-42. https://doi.org/10.1016/j.omega.2017.07.005.

Biglaiser, Gary, and Fei Li. 2018. "Middlemen: The Good, the Bad, and the Ugly." RAND Journal of Economics 49 (1): 3-22. https://doi.org/10.1111/1756-2171.12216.

Bonamini, Giorgio, Emanuela Colombo, Natividad Llorca, and Joaquin Sanchez-Soriano. 2019. "Cost Allocation for Rural Electrification Using Game Theory: A Case of Distributed Generation in Rural India." Energy for Sustainable Development 50: 139-52. https://doi.org/10.1016/j.esd.2019.01.007.

BPS. 2019. Indonesia Dalam Angka 2019 (In Number of Indonesia 2019). Jakarta: Badan Pusat Statistik.

Brown, Kevin Leyton, and Yoav Shoham. 2008. Essentials of Game Theory. California USA.: Morgan \& Claypool Publisher. https://doi.org/10.2200/So0108ED1Vo1Y200802AIMoo3.

Chandra, Yamini, and Prakash Sao. 2020. "Case Study on Salt Farmers: A Sustainable Livelihood Approach.” Indian Journal of Social Work 81 (1): 119-34. https://doi.org/10.32444/IJSW.2020.81.1.119-134.

Chen, Xu, Shuyao Wu, Xiaojun Wang, and Dong Li. 2018. "Optimal Pricing Strategy for the Perishable Food Supply Chain.” International Journal of Production Research 57 (9): 2755-68. https://doi.org/10.1080/00207543.2018.1557352.

Courtois, Piierre, and Julie Subervie. 2014. "Farmer Bargaining Power and Market Information Services." Amer. J. Agr. Econ. 97 (3): 953-77. https://doi.org/10.1093/ajae/aau051.

Deng, Hengshan, Jikun Huang, Zhigang Xu, and Scott Rozelle. 2010. "Policy Support and Emerging Farmer Professional Cooperatives in Rural China." China Economic Review 21 (4): 495-507. https://doi.org/10.1016/j.chieco.2010.04.009.

Deng, Mingjun, Guocheng Xiang, and Shuntian Yao. 2018. "The Effectiveness of the Multilateral Coalition to Develop a Green Agricultural Products Market in China Based on a TU Cooperative Game Analysis." Sustainability (Switzerland) $10 \quad$ (5): 1-17. https://doi.org/10.3390/su10051476.

Effendy, M, M Zainuri, and Hafiluddin. 2014. Intensifikasi Lahan Garam Rakyat Di Kabupaten Sumenep (Intensification of People's Salt Land in Sumenep Regency). Bangkalan: Marine Science Study Program, University of Trunojoyo Madura.

Ferguson, Thomas S. 2014. Game Theory, 2nd Edition. 2nd ed. Mathematics Department, UCLA. www.math.ucla.edu/ tom/Game_Theory/Contents.html.

Gao, Jinwu, Xiangfeng Yang, and Di Liu. 2017. "Uncertain Shapley Value of Coalitional Game with Application to Supply Chain Alliance." Applied Soft Computing Journal 56: 551-56. https://doi.org/10.1016/j.asoc.2016.06.018.

Grashuis, Jasper. 2018. "Joint Ownership by Farmers and Investors in the Agri-Food Industry: An Exploratory Study of the Limited Cooperative Association." Agricultural and Food Economics 6 (24). https://doi.org/10.1186/s40100-018-0118-0. 
Guarín, Alejandro. 2013. "The Value of Domestic Supply Chains: Producers, Wholesalers, and Urban Consumers in Colombia." Development Policy Review 31 (5): 511-30. https://doi.org/10.1111/dpr.12023.

Hansen, Bjørn Gunnar. 2015. "Financial Extension That Challenges Farmers' Thinking in Discussion Clubs Helps Farmers Improve Their Problem Solving Abilities." Agricultural Systems 132: 8592. https://doi.org/10.1016/j.agsy.2014.09.009.

Hao, Jinghui, Jos Bijman, Cornelis Gardebroek, Nico Heerink, Wim Heijman, and Xuexi Huo. 2018. "Cooperative Membership and Farmers ' Choice of Marketing Channels - Evidence from Apple Farmers in Shaanxi and Shandong Provinces , China is." Food Policy 74 (August 2016): 53-64. https://doi.org/10.1016/j.foodpol.2017.11.004.

Hennessy, Thia, and Kevin Heanue. 2012. "Quantifying the Effect of Discussion Group Membership on Technology Adoption and Farm Profit on Dairy Farms." Journal of Agricultural Education and Extension 18 (1): 41-54. https://doi.org/10.1080/1389224X.2012.638784.

Heriansah, and Fathuddin. 2014. "Analisis Tata Niaga Garam Untuk Pengembangan Usaha Rakyat Di Kabupaten Pangkep (Analysis on Salt Agribusiness to Develop Local Salt in Pangkep District)." Jurnal Balik Diwa 5 (2): 1-9.

Holis, Moh., Sayyidi Sayyidi, and Musoffan Musoffan. 2019. "Optimization Analysis of Salt Farmers Activities and Welfare in Pamekasan Regency.” Eaj (Economics and Accounting Journal) 2 (3): 198. https://doi.org/10.32493/eaj.v2i3.y2019.p198-205.

Jamil, Ahmad Syariful, and Tinaprilla Netti. 2015. "Pemasaran Garam Rakyat (Studi Kasus Desa Lembung, Kecamatan Galis, Kabupaten Pamekasan, Jawa Timur) (Marketing of Local Salt (a Case Study in Lembung Village, Galis Sub District, Pamekasan District, East Java))." Forum Agribisnis 5 (2): 121-38. https://doi.org/10.29244/fagb.5.2.121-138.

Joffre, Olivier M., P. Marijn Poortvliet, and Laurens Klerkx. 2019. "To Cluster or Not to Cluster Farmers? Influences on Network Interactions, Risk Perceptions, and Adoption of Aquaculture Practices.” Agricultural Systems 173 (July 2018): 151-60. https://doi.org/10.1016/j.agsy.2019.02.011.

KKP. 2019. "Tingkatkan Kualitas Garam, KKP Bangun Gudang Garam Nasional (Improving Salt Quality, KKP Builds National Salt Warehouse)." KKP, 2019. https://kkp.go.id/djprl/artikel/8948-tingkatkan-kualitas-garam-kkp-bangun-gudang-garamnasional.

Kontogeorgos, Achilleas, Panagiota Sergaki, Anastasia Kosma, and Vassiliki Semou. 2018. "Organizational Models for Agricultural Cooperatives: Empirical Evidence for Their Performance." Journal of the Knowledge Economy 9 (4): 1123-37. https://doi.org/10.1007/s13132-016-0402-8.

Liu, Yongsheng, Tong Han, and Xuan Wei. 2016. "Beijing Salt Company: The Way to Deal with the Salt Reform Program.” American Journal of Industrial and Business Management 06 (12): 1185-93. https://doi.org/10.4236/ajibm.2016.612109.

Liu, Zhibing, Chi Zhou, Huiru Chen, and Ruiqing Zhao. 2018. "Impact of Cost Uncertainty on Supply Chain Competition under Different Confidence Levels." International Transactions in Operational Research 00: 1-40. https://doi.org/10.1111/itor.12596.

Ma, Wangli, and Awudu Abdulai. 2016. "Does Cooperative Membership Improve Household Welfare? Evidence from Apple Farmers in China." Food Policy 58: 94-102. https://doi.org/10.1016/j.foodpol.2015.12.002.

Maflahah, Iffan, and Dian Farida Asfan. 2020. "Quality Characteristics of Salt Fortification with Dragon Fruit Peel in Plastic Packaging during Storage Period." Industria: Jurnal Teknologi Dan Manajemen Agroindustri 9 (1): 73-81. https://doi.org/10.21776/ub.industria.2020.009.01.9.

Mannar, Venkatesh, and Rizwan Yusufali. 2013. "Salt Production and Trade in Africa." IDD Newsletter 41 (4): 19-20.

Martins, Franco Müller, Jacques Trienekens, and Onno Omta. 2019. "Implications of Horizontal and Vertical Relationships on Farmers Performance in the Brazilian Pork Industry." Livestock Science 228 (April): 161-69. https://doi.org/10.1016/j.livsci.2019.08.013.

Maschler, M, E Solan, and S Zamir. 2013. Game Theory. Cambridge: Cambridge University Press. https://doi.org/https://doi.org/10.1017/CBO9780511794216. 
Milovanovic, Vladimir, and Lubos Smutka. 2018. "Cooperative Rice Farming within Rural Bangladesh." Journal of Co-Operative Organization and Management 6 (1): 11-19. https://doi.org/10.1016/j.jcom.2018.03.002.

Ming, Chen, Feng Junwen, and Li Xiaoyan. 2008. "A Study on Chinese Salt Monopoly Mechanism Innovation.” Management Science \& Engineering 2 (1): 77-85. http://search.ebscohost.com/login.aspx?direct=true\&db=a9h\&AN=32926394\&site=ehostlive.

Minoo, Arihiro. 2017. "Why Do Farmers Not Choose Fair Trade Cooperatives?: A Consideration Based on the Livelihood Strategy of Coffee Farmers in Lao PDR." Human Organization 76 (2): 131-40. https://doi.org/10.17730/o018-7259.76.2.131.

Muensriphum, C., S. Vichyavichien, S. Jinarach, P. Atthayuwat, and Bahaudin Mujtaba. 2010. "Strategic Exploration of Salt International Company in Thailand: Can They Have Sustainable Growth and Profits?” Journal of Business Studies Quarterly 1 (3): 68.

Muhandhis, Isnaini, Budisantoso Wirjodirdjo, Erma Suryani, Heri Susanto, and Ully Asfari. 2021. "Modeling of Salt Supply Chains to Achieve Competitive Salt Prices." International Journal on Food System Dynamics 12 (1): 51-67. https://doi.org/10.18461/ijfsd.v12i1.75.

Mustofa, Siti Komariyah, Lilis Yuliati, and Nely Supeni. 2021. "Development Strategy for Salt Farmers Market Access in East Java Indonesia: SWOT Analysis Approach.” International Journal of Social and Administrative Sciences 6 (1): 8-13. https://doi.org/10.18488/journal.136.2021.61.8.13.

Muthini, Davis. 2016. "An Assessment of Factors Affecting Choice of Market Channels among Mango Farmers in Makueni, Kenya AN ASSESSMENT OF MANGO FARMERS ' CHOICE OF MARKETING CHANNELS IN MAKUENI, KENYA FOR THE DEGREE OF MASTER OF SCIENCE IN AGRICULTURAL AND APPLIED,” no. September 2014. https://doi.org/10.13140/RG.2.1.2684.5200.

Naseer, Muhammad Asad Ur Rehman, Mubashir Mehdi, Muhammad Ashfaq, Sarfraz Hassan, and Muhammad Abid. 2019. "Effect of Marketing Channel Choice on the Profitability of Citrus Farmers: Evidence Form Punjab-Pakistan.” Pakistan Journal of Agricultural Sciences 56 (4): 1003-11. https://doi.org/10.21162/PAKJAS/19.8671.

Ndoro, Jorine T, Maxwell Mudhara, and Michael Chimonyo. 2014. "Farmers' Choice of Cattle Marketing Channels under Transaction Cost in Rural South Africa : A Multinomial Logit Model Farmers ' Choice of Cattle Marketing Channels under Transaction Cost in Rural South Africa : A." African Journal of Range \& Forage Science, 1-10. https://doi.org/10.2989/10220119.2014.959056.

Prasad, Sanjay, Ravi Shankar, and Sreejit Roy. 2019. "Impact of Bargaining Power on Supply Chain Profit Allocation: A Game-Theoretic Study." Journal of Advances in Management Research 16 (3): 398-416. https://doi.org/10.1108/JAMR-10-2018-0096.

Purnanto, Siwi Hadi, Suadi Suadi, and Ustadi Ustadi. 2020. "Salt Supply Chain Management at Regional Level: Case Study of Salt Processing Industry and Salt Consumer Industry in Central Java." Jurnal Perikanan Universitas Gadjah Mada 22 (1): 63. https://doi.org/10.22146/jfs.41194.

Pusat Kebijakan Perdagangan Dalam Negeri (Puska DN). 2012. "Penerapan Supply Chain Management Untuk Meningkatkan Efisiensi Dan Efektifitas Distribusi Pada Kasus Garam. Pusat Kebijakan Perdagangan Dalam Negeri (Application of Supply Chain Management to Improve Distribution Efficiency and Effectiveness in Salt Cases." Jakarta: Kementerian Perdagangan.

Rinardi, Haryono, and Yety Rochwulaningsih. 2017. "Salt Cooperatives as Public Credit Institutions for Coastal Communities : A Case Study of Two Salt Cooperatives in Rembang and Demak." Journal of Maritime Studies and National Integration 1 (1): 66-77.

Sasongko, Budi, Elfindri Elfindri, - Sjafrizal, Tafdil Husni, and Alpon Satrianto. 2019. "Production Optimalization Analysis and Maximization Profit of Salt Farmers on the Madura Island" 73 (Aicar 2018): 134-38. https://doi.org/10.2991/aicar-18.2019.28.

Sasongko, Budi, and Alpon Satrianto. 2021. "Factors Affecting Income Salt Farmers on the Island Madura" 18 (April). https://doi.org/10.14704/WEB/V18SIo3/WEB18033.

SAVE. 2005. "A Study of Salt Wolker of Kutch, Patan, Rajkot and Surendranagar District of Gujarat." Report. 
Shapley, Lloyd S. 1953. "A Value for N-Persons Games." In Contributions to the Theory of Games (AM-28), Volume II, 307-18. Princeton University Press.

Song, Cen, and Jun Zhuang. 2017. "Modeling a Government-Manufacturer-Farmer Game for Food Supply Chain Risk Management.” Food Control 78: 443-55. https://doi.org/10.1016/j.foodcont.2017.02.047.

Sudaryana, Bambang, and Puji Pramesti. 2018. "The Strategy of Welfare Improvement for Salt Farmers in Indonesia." MATEC Web of Conferences 150: 1-7. https://doi.org/10.1051/matecconf/201815005062.

Suhendi, Suhendi, Asaduddin Abdullah, and Fithriyyah Shalihati. 2020. "The Effectiveness of the Salt Policy in Indonesia." Jurnal Manajemen Dan Agribisnis 17 (3): 315-24. https://doi.org/10.17358/jma.17.3.315.

Tabrizi, Seyfollah, Seyed Hassan Ghodsypour, and Abbas Ahmadi. 2018. "Modelling Three-Echelon Warm-Water Fish Supply Chain: A Bi-Level Optimization Approach under Nash-Cournot Equilibrium." Applied Soft Computing Journal 71: 1035-53. https://doi.org/10.1016/j.asoc.2017.10.009.

Thomas, L.C. 1986. Games Theory \& Applications. Chichester: Ellis Horwood.

Watanabe, Makoto. 2018. "Middle Men: The Visible Market-Makers." The Journal of The Japanese Economic Association 69 (2): 156-70. https://doi.org/10.1111/jere.12168.

Widiyastutik, Manda Ayu, Triana Dewi Hapsari, and Ebban Bagus Kuntadi. 2016. "Pemasaran Garam Rakyat Di Desa Pangarengan Kecamatan Sampang (Marketing of Smallholder Salt in Village of Pangarengan, District of Pangarengan, Sampang Regency)." Agritrop: Jurnal IlmuIlmu Pertanian 14 (2): 222-30. https://doi.org/10.32528/agr.v14i2.437.

Wulandari, Vitri, Mahmud Yunus, Aryan Eka Prastya Nugraha, and Antono Herry Purnomo Adhi. 2021. "The Role of Capital Structure, Human Resources, and Technology in Increasing Salt Farmers' Income.” SOCA: Jurnal Sosial Ekonomi Pertanian 15 (1): 157-65.

Zhong, Zhen, Chen Zhang, Fu Jia, and Jos Bijman. 2018. "Vertical Coordination and Cooperative Member Benefits: Case Studies of Four Dairy Farmers' Cooperatives in China." Journal of Cleaner Production 172: 2266-77. https://doi.org/10.1016/j.jclepro.2017.11.184. 